\title{
Flying capacitors multilevel inverter: architecture, control and active balancing
}

\author{
Omar Bouamrane ${ }^{1}$, Tajeddine Khalili ${ }^{12}$, Ilham Tyass ${ }^{1}$, Mohamed Rafik ${ }^{1}$, Abdelhadi Raihani ${ }^{1}$, Lhoussain Bahati ${ }^{1}$, and \\ Bachir Benhala ${ }^{1}$ \\ ${ }^{1}$ ENSET-SSDIA Laboratry, Hassan II University of Casablanca, Casablanca, Morroco \\ ${ }^{2}$ ENSA Béni Mellal, TNAI Research Team, SULTAN MOULAY SLIMAN University, Béni Mellal, Morocco \\ ${ }^{3}$ Faculty of Science, Meknes, Morocco
}

\begin{abstract}
To improve efficiency and productivity of electric energy generators based on photovoltaic, wind or hybrid systems; several DC/AC conversion techniques have been developed and tested like multilevel inverters. Multilevel inverters are a performant solution for the ramp-up of converters. As soon as the DC supply voltage exceeds a few $\mathrm{kV}$, it is necessary to combine switches, switching cells or converters. This paper presents a progressive study of an interesting type of these inverters namely flying capacitor multilevel inverters (FCMLI): architecture, evolutions, benefits and inconvenient. In fact, we processed 3- and 5-level FCMLI while presenting possible circuit schemes and simulation results on Matlab Simulink. Finally, a general formulation has been adopted and applied to a 17 level FCMLI.
\end{abstract}

Keywords: multilevel inverter, FCMLI, flying capacitors, Matlab Simulink, cells, multi-cells inverters.

\section{Introduction}

In recent years, there has been an increase in industrial applications of multilevel inverters (locomotive, low induction bus bar, modular design ...), this is due to the quality of the output voltage of these converters and the efficiency of electric generators based on this type of technology [1], [2].

Multi-level conversion structures convert energy into medium or high voltage. This name comes from the fact that the waveforms of the output voltages allow to have more than two different voltage levels. These structures have been classified into different categories such as $\mathrm{H}$ bridge types, multicellular series or parallel converters, or structures using continuous bus splitting.

Multi-level techniques are an advanced solution in the rise of power of converters. As soon as the DC supply voltage exceeds a few $\mathrm{kV}$, it is necessary to combine switches, switching cells or converters

The emergence of serial multicellular converters in the early 1990s brought solutions through the elementary switching cell series. This topology ensures the distribution of switching stress on the various low-voltage semiconductor components connected in series. It also improves the output waveforms and in particular, the harmonic content, by an adequate offset of the control commands. The multicellular structure however requires the use of floating capacitors whose terminal voltages must be controlled and maintained at a well-defined level in order to ensure correct operating of the multilevel. [3].
In general, the modeling for the control of static converter presents a major difficulty linked to the fact that these systems include continuous variables (currents in the inductors, voltages at the terminals of the capacitors) and discrete variables (on state or blocked switches). Of course, it is in the sense of a macroscopic model that the switch has this binary character. In this article, we conduct a study of the multilevel floating capacitor inverter called FCMLI and the charge balancing aspects of capacitors.

A short review of the flying capacitors multilevel inverter is given, the description of the 3-level Flying capacitor converter along with load balancing is given. Afterwards, we present the details of the study of the 5levels converter. The final contribution on this research gives a formulation of the output voltage developed during this study for these particular flying capacitors MLI. This formulation aims to facilitate the studies and the development of control algorithms.

\section{FCMLI architecture}

\subsection{Multicellular Series Converter :}

The flying Capacitor Multilevel Inverter is an energy conversion topology, emerged in the early 1990s following a patent filed by Thierry A.Meynard and Henri Foch. The structure of the FC Series multicellular converter is based on the series of complementary switches known as switching cells between which a flying voltage source is inserted. Flying DC voltage sources are 
supplied by capacitors. This allows a multi-level tension, as well as other interesting properties. A good example of FCMLI application is active harmonic filtering due to the supply of non-linear or unbalanced loads to clean up the network [4]. This structure can operate in several configurations: CC-CC converter or inverter, half deck or full deck. [5].

This structure has several advantages such as:

- A good distribution of the voltage on each switch whatever the static or dynamic speed;

- Any combination can be made without reducing the life of the system;

- Switching "redundancies" in the operating sequences introduce states that can be used to maintain the charge balance of the capacitors.

- The use of components that maintain lower voltages increases the switching characteristics;

- Easily increase the voltage by increasing the number of cells thanks to its modular appearance

- However, it is necessary to integrate a large number of capacitors, especially for a threephase configuration. [6]

\subsection{Three levels FCMLI :}

The 2-cell FC converter (Fig.1) involves a series of two cells switching through a voltage source. This voltage source is produced by a flying capacitor. The DC bus can be formed by two identical voltage sources $\frac{V}{2}$ (fig. 1A), or by two identical capacitors (or group of capacitors for the balanced case) placed in parallel with the source of direct voltage $\mathrm{V}$ and separated by the mass point. (Fig. 1B)

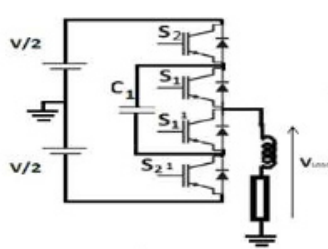

A
B

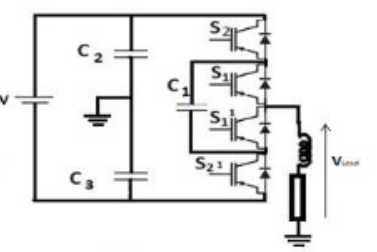

Fig. 1A \&B: 2-cell FC converter

To avoid any short-circuit of the voltage sources, the commands of switches (S1 \& S11) and (S2 \& S21), must be complementary. These two pairs of switches then form two switching cells.

The combination between the states of these two pairs of switches gives us $\left(2^{2}\right)$ four scenarios and we guarantee three values of the output voltage shown in the table below:
Table 1. Output states of a 3-level FC inverter

\begin{tabular}{|c|c|c|c|c|c|c|}
\hline \multirow[b]{2}{*}{ Vs } & \multicolumn{4}{|c|}{ Switch status } & \multicolumn{2}{|c|}{ Current flow path } \\
\hline & $\begin{array}{l}S \\
1\end{array}$ & $\begin{array}{l}S \\
2\end{array}$ & $\begin{array}{c}\mathrm{S} \\
11\end{array}$ & $\begin{array}{c}S \\
21\end{array}$ & Fig. 1A & Fig. 1B \\
\hline$\frac{\mathrm{V}}{2}$ & 1 & 1 & 0 & 0 & $\frac{\mathrm{V}}{2}-\mathrm{S} 2 \_\mathrm{S} 1$ & C2_S2_S1 \\
\hline 0 & 0 & 1 & 1 & 0 & $\begin{array}{c}\frac{\mathrm{V}}{2} \_\mathrm{S} 2 \_\mathrm{C} 1 \\
\text { _D11 }\end{array}$ & $\begin{array}{l}\text { C2_S2 } \\
\text { C1_D11 }\end{array}$ \\
\hline 0 & 1 & 0 & 0 & 1 & $\begin{array}{c}-\frac{\mathrm{V}}{2}-\mathrm{D} 211_{-} \\
\mathrm{C} 1 \_\mathrm{S} 1\end{array}$ & $\begin{array}{c}\text { C3_D21_- } \\
\text { C1_S1 }\end{array}$ \\
\hline$\frac{\mathrm{V}}{2}$ & 0 & 0 & 1 & 1 & $\begin{array}{c}-\frac{\mathrm{V}}{2}-\mathrm{D} 2- \\
\mathrm{D} 1\end{array}$ & $\begin{array}{c}\text { C3_D21_ } \\
\text { D1 }\end{array}$ \\
\hline
\end{tabular}

The cell assembly and the flying voltage source linked to this cell are called a module.

In the case of Fig.1 A, we have:

$>2$ cells: $\{\mathrm{S} 1 ; \mathrm{S} 11\}$ and $\{\mathrm{S} 2 ; \mathrm{S} 21\}$

$>1$ module: $\{\mathrm{S} 1 ; \mathrm{S} 11 ; \mathrm{C} 1\}$.

The expression of the output voltage Vs, according to the mesh law, is as follows:

$$
\begin{gathered}
V_{S}=\frac{V}{2}\left(S_{2}-S_{21}\right)+V_{\text {modulel }} \\
V_{S}=\frac{V}{2}\left(S_{2}-\overline{S_{2}}\right)+V_{\text {module }} \\
V_{S}=\frac{V}{2}\left(S_{2}-\overline{S_{2}}\right)+V_{C l}\left(S_{1}-S_{2}\right)
\end{gathered}
$$

$V_{C 1}$ is the voltage at the terminal of capacitor $\mathrm{C} 1$.

In fig.1.B: The voltage across the load is:

$$
\begin{gathered}
V_{S}=V_{C 2} * S_{2}-V_{C 3} * S_{21}+V_{C 1}\left(S_{1}-S_{2}\right) \\
V_{S}=V_{C 2} *\left(S_{2}-S_{21}\right)+V_{C l}\left(S_{1}-S_{2}\right) \\
V_{S}=V_{C 2} *\left(S_{2}-\bar{S}_{2}\right)+V_{C l}\left(S_{1}-S_{2}\right)
\end{gathered}
$$

After simulation on Matlab Simulink, we find the following results:

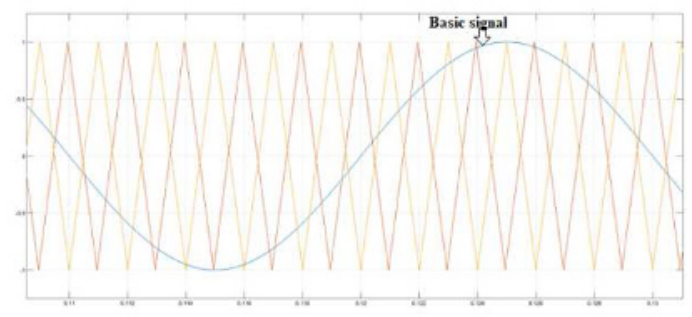

Fig. 2. Basic signal and the two carriers for controlling the two switches

Two carriers, offset by $\frac{2 \pi}{2}$, provide control, which makes it possible to alternate between the two combinations to have the value " 0 " of the output voltage.

\footnotetext{
${ }^{*} \mathrm{Di}$ is the clamp diode of the Si switch
} 


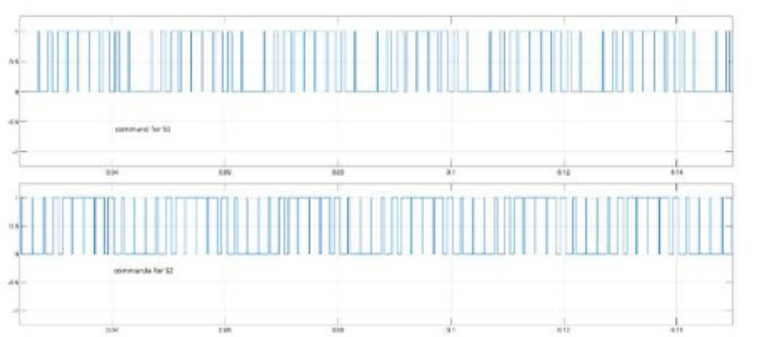

Fig. 3. Control signal for $\mathrm{S} 1$ and $\mathrm{S} 2$

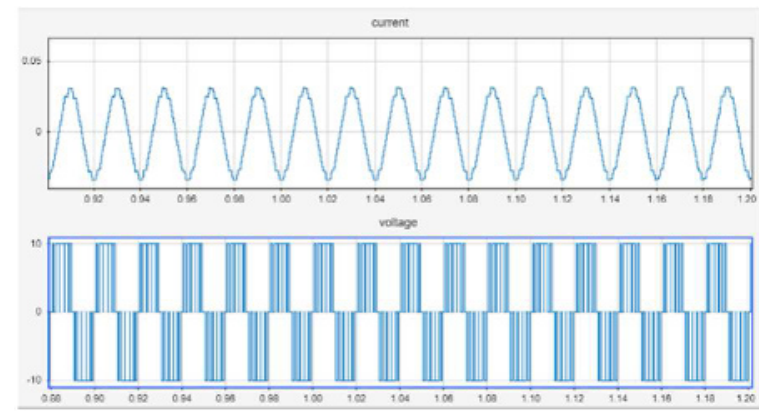

Fig.4. voltage and current at the 3-level FC load

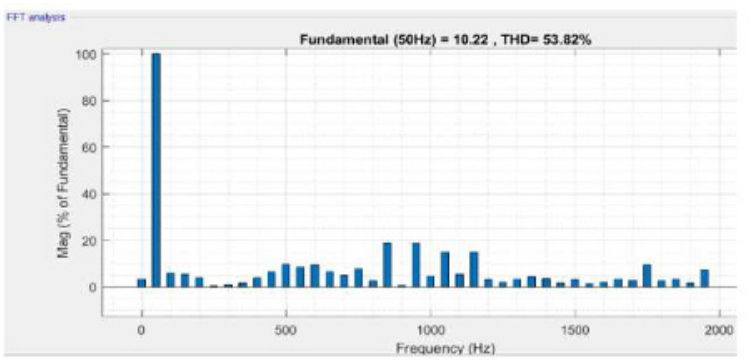

Fig. 5. Analysis spectrum of the output voltage for a 3-level FC inverter

The FFT analys of the signals shows that the harmonics are repelled at high frequencies. This will facilitate filtering if necessary.

\subsection{Five levels FCMLI:}

The 5-level FC converter (Fig. 6) is formed by putting four switching cells in series (a converter pair and a floating voltage source). The DC bus can be produced either by two identical $\frac{V}{2}$ voltage sources (Fig. 6A) or by two identical capacitors (or group of capacitors for the balanced case) placed in parallel with the DC voltage source V. (Fig. 6B).

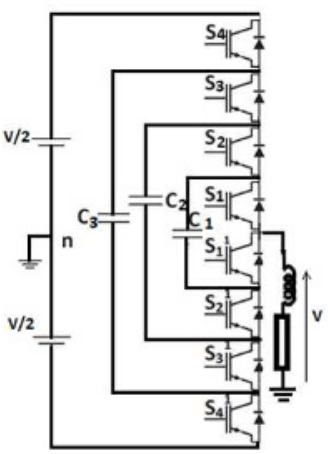

A

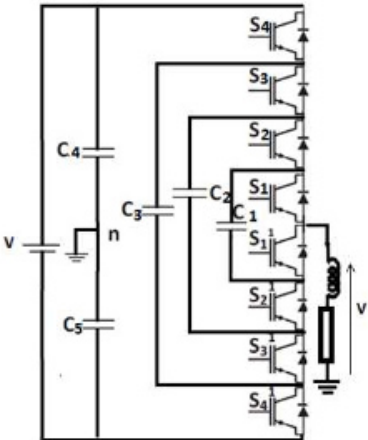

B

Fig. 6.A \& B: 5-level FC inverter structure

The four pairs of switches that form the four 5-level FCMLI cells are (S1 \& S11), (S2 \& S22), (S3 \& S31) and (S4 \& S41). Moreover, to avoid short-circuiting the voltage sources, the switch commands must be complementary. The combination of the states of these four pairs of switches provides $(4+1)$ five output voltage levels $-\frac{V}{2},-\frac{V}{4}, 0, \frac{V}{4}$ and $\frac{V}{2}$. The table below shows the sixteen $\left(2^{4}\right)$ possible cases:

Table 2. Output states of a 5-level FC inverter

\begin{tabular}{|c|c|c|c|c|c|c|c|c|c|c|}
\hline Case & Vs & $\begin{array}{l} \\
1\end{array}$ & $\begin{array}{l}\mathbf{S} \\
2\end{array}$ & $\begin{array}{l}\mathbf{S} \\
3\end{array}$ & \begin{tabular}{l|}
$S$ \\
4 \\
\end{tabular} & $\begin{array}{c} \\
11\end{array}$ & \begin{tabular}{|c|} 
\\
21
\end{tabular} & \begin{tabular}{|c|}
$S$ \\
31
\end{tabular} & \begin{tabular}{|c|}
$S$ \\
41
\end{tabular} & $\begin{array}{c}\text { Current flow } \\
\text { path }\end{array}$ \\
\hline 1 & \multirow{6}{*}{0} & 0 & 0 & 1 & 1 & 1 & 1 & 0 & 0 & $\begin{array}{c}\text { C4_S4_S3 } \\
\text { C2_D21_D1 } \\
1\end{array}$ \\
\hline 2 & & 1 & 1 & 0 & 0 & 0 & 0 & 1 & 1 & $\begin{array}{c}\text { C5_D41_D3 } \\
\text { 1_C2_S2_S } \\
1\end{array}$ \\
\hline 3 & & 0 & 1 & 0 & 1 & 1 & 0 & 1 & 0 & \begin{tabular}{|c|} 
C4_S4_C3 \\
D31_C2_- \\
S2 C1 D11
\end{tabular} \\
\hline 4 & & 1 & 0 & 0 & 1 & 0 & 1 & 1 & 0 & $\begin{array}{c}\text { C4_S4_C3_- } \\
\text { D31_D21_C } \\
2 \_S 1\end{array}$ \\
\hline 5 & & 1 & 0 & 1 & 0 & 0 & 1 & 0 & 1 & $\begin{array}{c}\text { C5_D41_C3_ } \\
\text { S3_C2_D21_ } \\
\text { C1_S1 }\end{array}$ \\
\hline 6 & & 0 & 1 & 1 & 0 & 1 & 0 & 0 & 1 & $\begin{array}{c}\text { C4_D41_C3_ } \\
\text { S3_S2_C1_ } \\
\text { D11 }\end{array}$ \\
\hline 7 & \multirow{4}{*}{$\overline{4}$} & 0 & 1 & 1 & 1 & 1 & 0 & 0 & 0 & \begin{tabular}{|l|} 
C4_S4_S3_- \\
S2_C1_D11 \\
\end{tabular} \\
\hline 8 & & 1 & 1 & 1 & 0 & 0 & 0 & 0 & 1 & $\begin{array}{c}\text { C5_D41_C3_ } \\
\text { S3_S2_S1 }\end{array}$ \\
\hline 9 & & 1 & 1 & 0 & 1 & 0 & 0 & 1 & 0 & $\begin{array}{c}\text { C4_S4_C3_- } \\
\text { D31_C2_S2_ } \\
\text { S1 }\end{array}$ \\
\hline 10 & & 1 & 0 & 1 & 1 & 0 & 1 & 0 & 0 & $\begin{array}{c}\text { C4_S4_S3_C } \\
\text { 2_D21_C1_ } \\
\text { S1 }\end{array}$ \\
\hline 11 & $\frac{\mathrm{V}}{2}$ & 1 & 1 & 1 & 1 & 0 & 0 & 0 & 0 & $\begin{array}{c}\text { C4_S4_S3_S } \\
\text { 2_S1 }\end{array}$ \\
\hline 12 & \multirow{4}{*}{$\frac{\mathrm{V}}{4}$} & 1 & 0 & 0 & 0 & 0 & 1 & 1 & 1 & $\begin{array}{c}\text { C5_D41_D3 } \\
\text { 1_D21_C1_ } \\
\text { S1 }\end{array}$ \\
\hline 13 & & 0 & 0 & 1 & 0 & 1 & 1 & 0 & 1 & $\begin{array}{c}\text { C5_D41_C3_ } \\
\text { S3_C2_D21_ } \\
\text { D11 }\end{array}$ \\
\hline 14 & & 0 & 0 & 0 & 1 & 1 & 1 & 1 & 0 & $\begin{array}{c}\text { C4_S4_C3_- } \\
\text { D31_D21_D } \\
11\end{array}$ \\
\hline 15 & & 0 & 1 & 0 & 0 & 1 & 0 & 1 & 1 & $\begin{array}{c}\text { C5_D41_D3 } \\
\text { 1_C2_S2_C } \\
1 \_ \\
\text {D11 }\end{array}$ \\
\hline 16 & $-\frac{\mathrm{V}}{2}$ & 0 & 0 & 0 & 0 & 1 & 1 & 1 & 1 & $\begin{array}{c}\text { C5_D41_D3 } \\
\text { 1_D21_D11 }\end{array}$ \\
\hline
\end{tabular}

In Fig.7 below, we show examples of possible cases for reaching voltage levels. The control is ensured by four carriers phase shifted by $\frac{2 \pi}{4}$. 

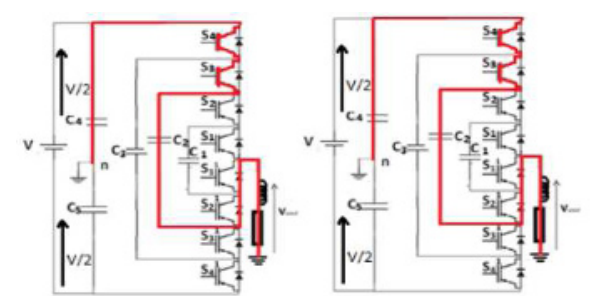

Case 1

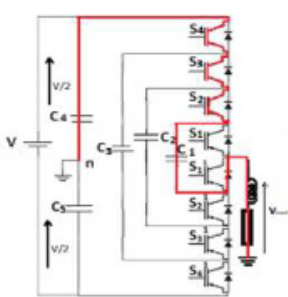

Case 2

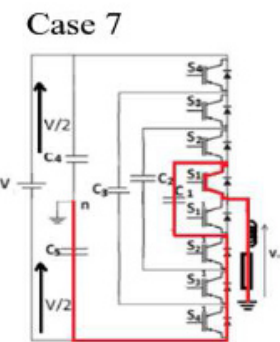

Case 12

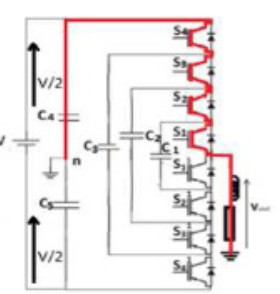

Case11

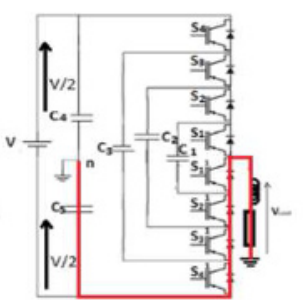

Case 16
Fig.7. Examples of possible cases for the values of the output voltage Vs

The expression of the output voltage Vs, according to the mesh law, is as follows:

In Fig. 6A, we have:

Cells: $\{\mathrm{S} 1 ; \mathrm{S} 11\} ;\{\mathrm{S} 2 ; \mathrm{S} 21\} ;\{\mathrm{S} 3 ; \mathrm{S} 31\} ;\{\mathrm{S} 4 ; \mathrm{S} 41\}$

Modules : $\{\mathrm{S} 1 ; \mathrm{S} 11 ; \mathrm{C} 1\} ;\{\mathrm{S} 2 ; \mathrm{S} 21 ; \mathrm{C} 2\} ;\{\mathrm{S} 3 ; \mathrm{S} 31 ; \mathrm{C} 3\}$

$$
\begin{aligned}
& V_{S}=\frac{V}{2}\left(S_{4}-S_{41}\right)+V_{\text {module } 3}+V_{\text {module } 2}+V_{\text {module } 1} \\
& V_{S}=\frac{V}{2}\left(S_{4}-S_{41}\right)+V_{C 3}\left(S_{3}-S_{4}\right)+V_{C 2}\left(S_{2}-S_{3}\right)+V_{C 1}\left(S_{1}-S_{2}\right)
\end{aligned}
$$

In fig. 6B: The voltage across the load is:

$$
V_{S}=V_{C 4} S_{4}-V_{C 5} S_{41}+V_{\text {module } 3}+V_{\text {module } 2}+V_{\text {module } 1}
$$

$V_{S}=V_{C 4} S_{4}-V_{C 5} S_{41}+V_{C 3}\left(S_{3}-S_{4}\right)+V_{C 2}\left(S_{2}-S_{3}\right)+V_{C 1}\left(S_{1}-S_{2}\right)(10)$ (C4=C5)

$V_{S}=V_{C 4}\left(S_{4}-S_{41}\right)+V_{C 3}\left(S_{3}-S_{4}\right)+V_{C 2}\left(S_{2}-S_{3}\right)+V_{C 1}\left(S_{1}-S_{2}\right)$

With $V_{\text {module } i}=V_{C i}\left(S_{i}-S_{i+1}\right) ; \mathrm{i}=\{1 ; 2 ; 3\}$.

After Matlab simulation, we find the following results:

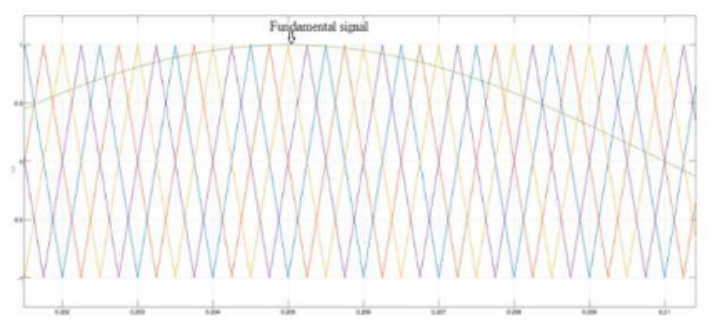

Fig. 8. : Fundamental signal and the 4 carriers for controlling the switches
The control is provided by four carriers phase shifted by $\frac{2 \pi}{4}$ which allows to alternate between the combinations to have the value 0 of the output voltage.

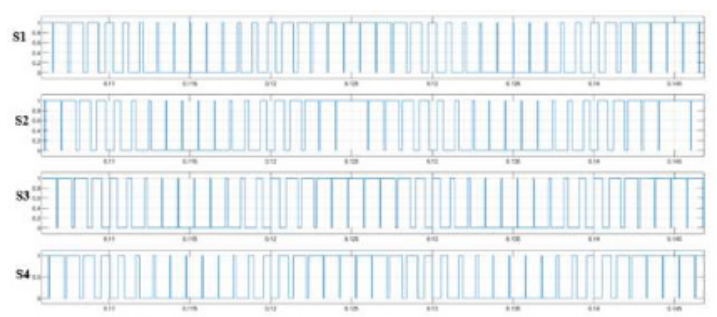

Fig. 9. Control signal for S1, S2, S3 and S4

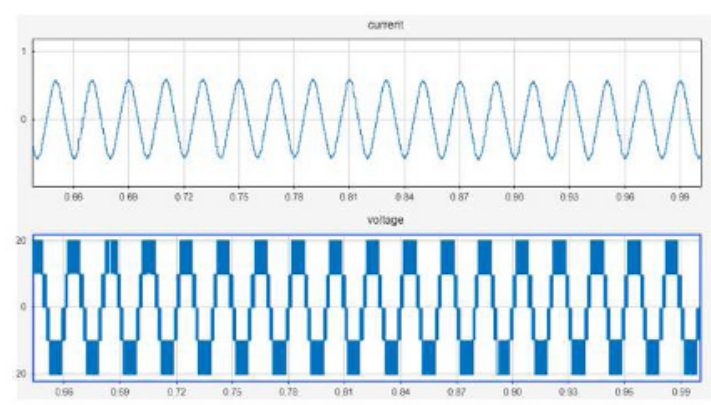

Fig. 10. Voltage and current at the FC load 5 levels

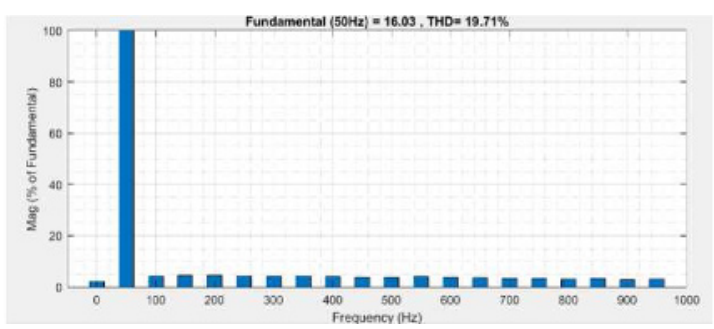

Fig.11. Output voltage analysis spectrum for a 5-level FC inverter

The harmonic spectrum of the obtained signals shows that the harmonics are pushed back to high frequencies. Furthermore, their values are less important and we notice a great decrease of the THD in comparison with the spectrum of the 3-level inverter.

\subsection{General conception of FCMLI architecture (N levels approach) :}

Obtaining three voltage levels by putting two switching cells in series (Fig. 1A\&B) gives us the possibility to create $n$ levels by putting $\mathrm{p}$ switching cells in series (Fig. 12). With the same condition that the two switches of the switching cell, have complementary controls to avoid short circuits. 


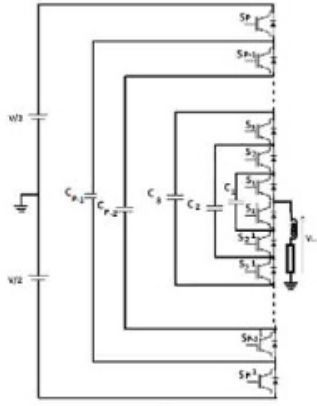

A

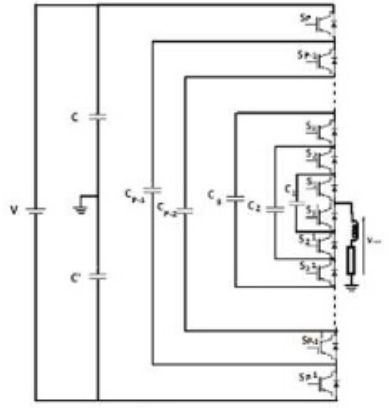

B
Fig. 12. A \& B: Inverter structure FC n levels with p cells

The following table summarizes the number of component and combinations according to inverter level FC

Table 3. Different parameters of the FC inverters

\begin{tabular}{|c|c|c|c|c|c|c|}
\hline $\mathbf{N}$ & $\mathbf{S}$ & $\mathbf{K}$ & $\mathbf{N c}$ & $\mathbf{D}$ & $\mathbf{D c}$ & $\mathbf{C}$ \\
\hline 3 & 2 & 4 & 4 & 4 & 0 & 1 \\
\hline 5 & 4 & 8 & 16 & 8 & 0 & 6 \\
\hline $\mathrm{n}$ & $(\mathrm{n}-1)$ & $2(\mathrm{n}-1)$ & $2^{\mathrm{p}}=2^{\mathrm{n}-1}$ & $2(\mathrm{n}-1)$ & 0 & $(\mathrm{n}-1)(\mathrm{n}-2) / 2$ \\
\hline
\end{tabular}

With: N: the number of voltage levels obtained,

$S$ : the number of DC sources,

Nc: number of possible switch combinations,

$\mathrm{K}$ : the number of main switches,

$\mathrm{D}$ : the number of main diodes,

Dc: the number of clamped diodes,

$\mathrm{C}$ : the number of balancing capacitors.

The combination between the states of these $p$ pairs of switches gives us $\left(2^{p}\right)$ cases and $n$ values of the output voltage, which corresponds to $\mathrm{n}=\mathrm{P}+1$ levels. All possible configurations are written: $\{0,1\}^{p}$.

The expression of the output voltage Vs, according to the mesh law, is as follows:

We have in fig. 12A: p cells, p- 1 capacitors and p-1 modules:

$$
\begin{gathered}
V_{S}=\frac{V}{2}\left(S_{p}-\overline{S_{p}}\right)+\sum_{j=1}^{p-1} V_{\text {module } j} \\
V_{S}=\frac{V}{2}\left(2 S_{p}-1\right)+\sum_{j=1}^{p-1} V_{C j}\left(S_{j}-S_{j+1}\right) \\
V_{S}=\frac{V}{2}\left(2 S_{p}-1\right)+\sum_{j=1}^{p-1} V_{C j}\left(S_{j}-S_{j+1}\right)
\end{gathered}
$$

The use of a switching cell allows a variation of the voltage between two levels of $\mathrm{V}$. The variation between two levels for the case of 3-level FC is equal to $\frac{\mathrm{V}}{2}$ (fig1). The extension for a p-cell series multi-cell structure allows having an output voltage variation between two levels of $\frac{\mathrm{V}}{\mathrm{P}}$.

In fact, if the voltage of each cell is defined by:

$$
V_{\text {cell } j}=V_{C j}-V_{C j-1}
$$

Equation 14 becomes, with $V_{C 0}=0$ et $V_{C p}=V$ :

$$
\begin{aligned}
& V_{S}=-\frac{V}{2}+\sum_{j=1}^{p} S_{j}\left(V_{C j}-V_{j-1}\right) \\
& V_{S}=-\frac{V}{2}+\sum_{j=1}^{p} S_{j} V_{\text {Cell }}
\end{aligned}
$$

In the equilibrium state, the voltage at the terminal of each cell must be equal to $V_{\text {Cell_ref }}=\frac{\mathrm{V}}{2}$
This will impose the values of the different sources of floating voltage (modules). Indeed, to ensure the voltage withstand for each component, the floating voltage sources must have the value, for $\mathrm{j}=\{1 ; 2 ; \ldots ; \mathrm{p}-1\}$ :

$$
V_{\text {modulej }}=j * \frac{V}{p}
$$

On the other hand, by replacing the cell voltage with the reference voltage, equation 17 becomes

\begin{tabular}{|c|c|c|c|c|c|c|c|c|c|c|c|c|}
\hline Case & $\mathbf{V}_{\mathbf{s}}$ & $\begin{array}{l}S \\
1\end{array}$ & $\begin{array}{l}S \\
2\end{array}$ & $\begin{array}{l}\mathbf{S} \\
\mathbf{3}\end{array}$ & $\begin{array}{l}S \\
4\end{array}$ & $\begin{array}{c}S \\
11\end{array}$ & $\begin{array}{c}\mathbf{S} \\
21\end{array}$ & & & $\begin{array}{c}S \\
41\end{array}$ & $\sum_{j=1}^{\alpha=} S_{j}$ & 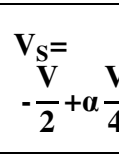 \\
\hline 1 & \multirow{6}{*}{0} & 0 & 0 & 1 & 1 & 1 & 1 & & 0 & 0 & 2 & $-\frac{V}{2}+2 \frac{V}{4}$ \\
\hline 2 & & 1 & 1 & 0 & 0 & 0 & 0 & 1 & 1 & 1 & 2 & $-\frac{V}{2}+2 \frac{V}{4}$ \\
\hline 3 & & 0 & 1 & 0 & 1 & 1 & 0 & 1 & 1 & 0 & 2 & $-\frac{V}{2}+2 \frac{V}{4}$ \\
\hline 4 & & 1 & 0 & 0 & 1 & 0 & 1 & 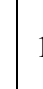 & 1 & 0 & 2 & $-\frac{V}{2}+2 \frac{V}{4}$ \\
\hline 5 & & 1 & 0 & 1 & 0 & 0 & 1 & ( & 0 & 1 & 2 & $-\frac{V}{2}+2 \frac{V}{4}$ \\
\hline 6 & & 0 & 1 & 1 & 0 & 1 & 0 & ( & 0 & 1 & 2 & $-\frac{V}{2}+2 \frac{V}{4}$ \\
\hline 7 & \multirow{4}{*}{ V } & 0 & 1 & 1 & 1 & 1 & 0 & ( & 0 & 0 & 3 & $-\frac{V}{2}+3 \frac{V}{4}$ \\
\hline 8 & & 1 & 1 & 1 & 0 & 0 & 0 & ( & 0 & 1 & 3 & $-\frac{V}{2}+3 \frac{V}{4}$ \\
\hline 9 & & 1 & 1 & 0 & 1 & 0 & 0 & 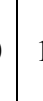 & 1 & 0 & 3 & $-\frac{V}{2}+3 \frac{V}{4}$ \\
\hline 10 & & 1 & 0 & 1 & 1 & 0 & 1 & ( & 0 & 0 & 3 & $-\frac{V}{2}+3 \frac{V}{4}$ \\
\hline 11 & $\frac{\mathrm{V}}{2}$ & 1 & 1 & 1 & 1 & 0 & 0 & ( & 0 & 0 & 4 & $-\frac{V}{2}+4 \frac{V}{4}$ \\
\hline 12 & \multirow{4}{*}{$-\frac{V}{4}$} & 1 & 0 & 0 & 0 & 0 & 1 & 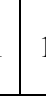 & 1 & 1 & 1 & $-\frac{V}{2}+\frac{V}{4}$ \\
\hline 13 & & 0 & 0 & 1 & 0 & 1 & 1 & ( & 0 & 1 & 1 & $-\frac{V}{2}+\frac{V}{4}$ \\
\hline 14 & & 0 & 0 & 0 & 1 & 1 & 1 & 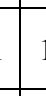 & 1 & 0 & 1 & $-\frac{\mathrm{V}}{2}+\frac{\mathrm{V}}{4}$ \\
\hline 15 & & 0 & 1 & 0 & 0 & 1 & 0 & 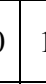 & 1 & 1 & 1 & $-\frac{V}{2}+\frac{V}{4}$ \\
\hline 16 & $-\frac{\mathrm{V}}{2}$ & 0 & 0 & 0 & 0 & 1 & 1 & 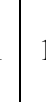 & 1 & 1 & 0 & $-\frac{\mathrm{V}}{2}+0$ \\
\hline
\end{tabular}

$$
\begin{gathered}
V_{S}=-\frac{V}{2}+V_{\text {Cell_ref }} \sum_{j=1}^{p} S_{j} \\
V_{S}=-\frac{V}{2}+\alpha \frac{V}{p} \quad \text { With } \alpha=\sum_{\mathrm{j}=1}^{\mathrm{p}} \mathrm{S}_{\mathrm{j}}
\end{gathered}
$$

Application for the case of 5 levels, we have $\mathrm{P}=4$; $\mathrm{V}_{\text {Cell_ref }}=\frac{\mathrm{V}}{4}$

Table 4. Output voltage values of the 5-level FC inverter 


\subsection{Application for the 17-level FC case:}

Table 5. Different 17-level FC inverter settings

\begin{tabular}{|c|c|c|c|c|r|c|}
\hline $\mathbf{N}$ & $\mathbf{S}$ & $\mathbf{K}$ & $\mathbf{N c}$ & $\mathbf{D}$ & $\mathbf{D c}$ & $\mathbf{C}$ \\
\hline 17 & 16 & 32 & $2^{16}$ & 32 & 0 & 120 \\
\hline $\mathrm{N}$ & $(\mathrm{n}-1)$ & $2(\mathrm{n}-1)$ & $2^{\mathrm{p}}=2^{\mathrm{n}-1}$ & $\begin{array}{c}2(\mathrm{n}- \\
1)\end{array}$ & 0 & $(\mathrm{n}-1)^{*}(\mathrm{n}-2) / 2$ \\
\hline
\end{tabular}

$\mathrm{N}$ : the number of voltage levels obtained,

$\mathrm{S}$ : the number of DC sources,

Nc: number of possible switch combinations,

$\mathrm{K}$ : the number of main switches,

$\mathrm{D}$ : the number of main diodes,

Dc: the number of clamped diodes,

$\mathrm{C}$ : the number of balancing capacitors.

The control is ensured by sixteen carriers shifted by $\frac{2 \pi}{16}$ which makes it possible to alternate between the combinations to have the value 0 of the output voltage.

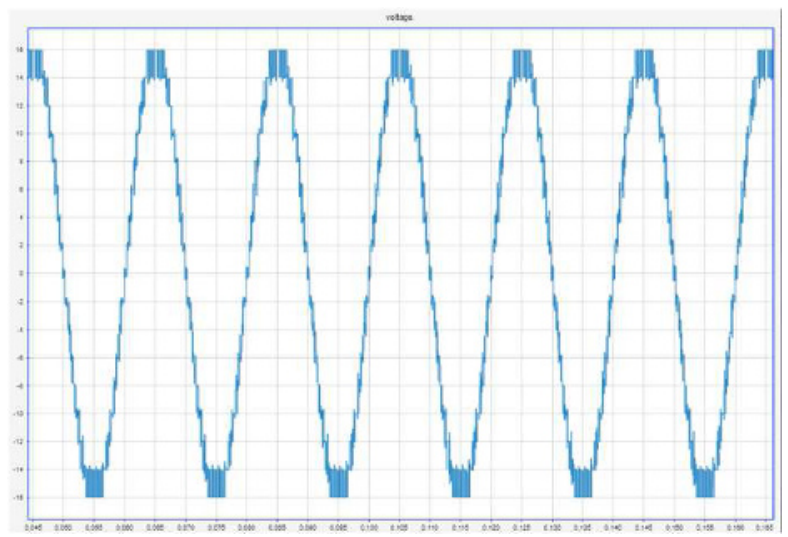

Fig. 13. FC 17-level exit voltage

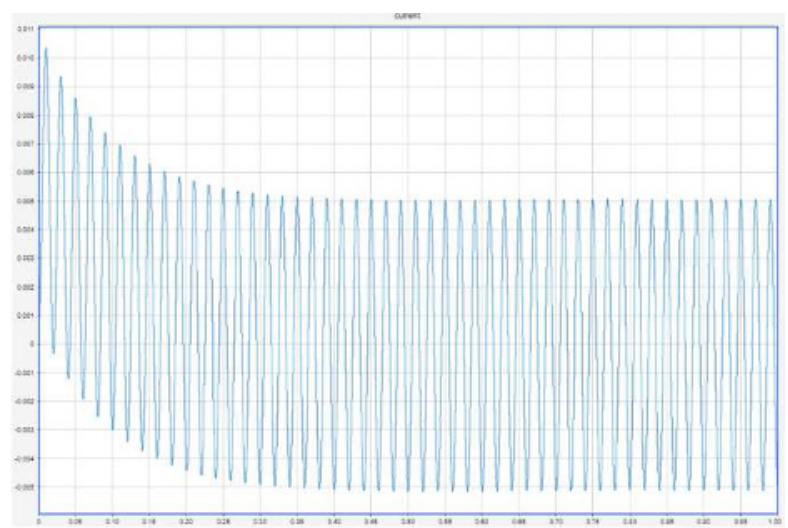

Fig. 14. Current in charge for FC 17 levels

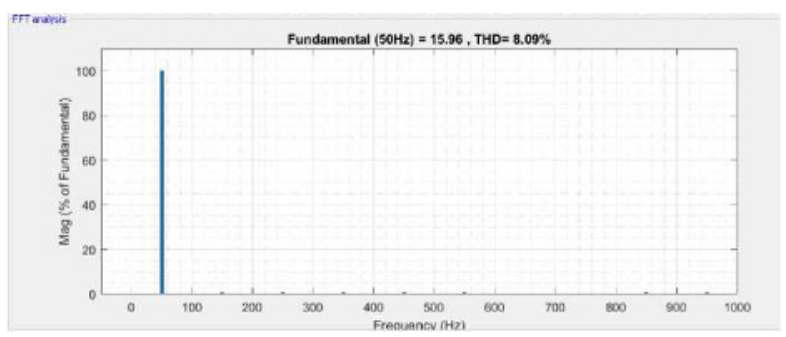

Fig. 15. Exit Tension Analysis Spectrum for a 17-level FC inverter
The harmonic spectrum of the resulting signals shows a minimal harmonics content and a large decrease in THD compared to the 5-level inverter spectrum.

\section{Conclusion:}

In this article, we have presented a detailed study on FC type multilevel inverters: history, architectures, evolution, advantages and disadvantages. Then, we focused on the 3 and 5 level FCMLI by studying the possible cases, the circuit diagrams and the results of simulations on Matlab Simulink.

Finally, we have proposed, based on the carried out studies, a general formulation of the output voltage given by FC type inverters, which will subsequently allow the development of a control algorithm for this type of inverter.

\section{References}

1. T.Meynard, H. Foch, P. Thomas, J. Courault, R. Jacob, andM. Nahrstaedt, "Multicell converters: Basic concepts and industry applications," IEEE Trans. Ind. Electron., vol. 49, no. 5, pp. 955-964, Oct. (2002).

2. D. Krug, M. Malinowski, and S. Bernet, "Design and comparison of medium voltage multi-level converters for industry applications," in Conf. Rec. 39th IEEE IAS Annu. Meeting, (2004), vol. 2, pp. 781-790.

3. R.BENSAID. Observateur des tensions aux bornes des capacités flottantes pour les convertisseurs multicellulaires séries. Thèse de doctorat, Institut National Polytechnique de Toulouse, (2001).

4. T.A. Meynard, H.Foch, "Multi-level Conversion: High Voltage Choppers and Voltage-Source Inverter", IEEE Power Electronics specialist Conference, (1992), pp.397-403

5. A.Bouarfa, M.Bodson, M. Fadel. Méthode d'allocation pour la commande en tension et l'équilibrage actif d'un onduleur multicellulaire à condensateurs flottants. Automatique Control, ISTE, (2018), 2 (1), 10.21494/ISTE.OP.2018.0300. hal01906313

6. HAL Id: hal-00749953 https://hal.inria.fr/hal00749953 Submitted on 8 Nov (2012).

7. Ph. Djondine. Etude des comportements chaotiques dans les convertisseurs statiques. Traitement du signal et de l'image. Université de Cergy Pontoise, (2015).

8. F. Defay, A. M. Llor, and M. Fadel. A Predictive Control with Flying Capacitor Balancing of a Multicell Active Power Filter. IEEE Transactions on Industrial Electronics, 55(9):3212-3220, September (2008).

9. G.Carrara, S.Gardella, M.Marchesoni, Member, IEEE, R.Salutari, and G.Sciutto. A New Multilevel PWM Method: A Theoretical Analysis 
10. T.A.MEYNARD, M.FADEL N.AOUDA, « Modeling of multilevel converters, » IEEE Trans. Indus. Electron., vol. 44, p. 356-364, (1997).

11. G.GATEAU, M.FADEL, P.MAUSSION, R.BENSAID, T.MEYNARD, « Multicell converters: active control and observation of flying-capacitor voltages, » IEEE Trans. Indus. Electron., vol. 49, p. 998-1008, (2002).

12. R.H.WILKINSON, T.A.MEYNARD, H.DU TOIT MOUTON, « Natural Balance of Multicell Converters: The General Case, » IEEE Trans. Power Electron. vol. 21, p. 1658-1666, (2006).

13. B.P.MCGRATH, D.G.HOLMES, « Analytical Modelling of Voltage Balance Dynamics for a Flying Capacitor Multilevel Converter, » IEEE Trans. Power Electron. vol. 23, p. 543-550, (2008).

14. B.REZNIKOV, A.RUDERMAN, « Four-Level Single-Leg Flying Capacitor Converter Voltage Balance Dynamics Analysis, » in IEEE EPE, Barcelone, Espagne, Fév. (2009).

15. G. Gateau, M. Fadel, P. Maussion, R. Bensaid, and T.A. Meynard. Multicell converters: active control and observation of _ying-capacitor voltages. IEEE Transactions on Industrial Electronics, 49(5): 9981008, October (2002).

16. N.Nagalakshmi, U. Ramesh Babu, Syed Munvar, aliK.Sudheer. A Single Phase Nine Level Inverter with Reduced Switches. IEEE International Conference on Power, Control, Signals and Instrumentation Engineering (ICPCSI-2017)

17. T.KHALILI, A.Raihani, H. Ouajji, O. Bouattane, F. Amri. Efficient Choice of a Multilevel Inverter for Integration on a Hybrid Wind-Solar Power Station. Journal of Power and Energy Engineering, (2015), 3, 44-58

18. M.RAFIK, T.KHALILI, O.BOUAMRANE, A.RAIHANI. A modified cascaded cells multilevel inverter with batteries state of charge adjustment. JATIT 15th September 2021 -- Vol. 99. No. 17 (2021)

19. Ph.Djondiné, M.Ghanes, J.P.Barbot, B.Essimbi. Dynamical Behaviors of Multicellular Chopper. Journal of Control Science and Engineering, David Publishing Company, (2014), 2 (1), pp.35 - 42. hal01075339

20. L.Amet, M.Ghanes, J.P.Barbot. Commande directe d'un convertisseur multicellulaire: résultats expérimentaux. CIFA - 7ème Conférence Internationale Francophone d'Automatique (2012), Jun 2012, Grenoble, France. hal-00749953 